\title{
Qualitative Contours: A New Geochemical Method for Preliminary Mineral Exploration
}

\author{
Mohammadreza Agharezaei \\ Department of Mining and \\ Metallurgy Engineering, \\ Amirkabir University of \\ Technology (Tehran \\ Polytechnic), Tehran, Iran
}

\author{
Hossein Hajari \\ Department of Mining \\ Engineering, University of \\ Birjand, South Khorasan \\ Province, Birjand, Iran
}

\author{
Ardeshir Hezarkhani \\ Department of Mining and \\ Metallurgy Engineering, \\ Amirkabir University of \\ Technology (Tehran \\ Polytechnic), Tehran, Iran
}

\begin{abstract}
The target in this paper is introduction and application of a new exploration method to locate and highlight mineral deposits and mineralization trends. Generally exploration methods could be categorized into two major groups; quantitative and qualitative methods. Although many attempts have been taken to progress the first group, the second one has not been considered and improved as it should have been. This research offers a new method named 'Qualitative Contours' which is descriptive rather than being numeric. This new method is applied to delineate mineralization trends and deposits locations in Qaleh-Zari area. The selected study area is located north west of Qaleh-Zari copper deposit. This area is selected to determine how effective this method is to find mineralization trends and the known Qaleh-Zari deposit. Theis new method "Qualitative Contours" successfully located Qaleh-Zari deposit and mineralization trends in the area. Beside the main function of this method, other beneficial performances are discussed such as lithology modeling and erosion levels estimation which are highly correlated to field observations in the area. In this research, locating the well-known Qaleh-Zari copper deposit as the result of the Qualitative Contours method is discussed and in order to prove the accuracy of such locating, Concentration-Volume (C-V) Fractal modeling is used to prove copper anomalies numerically.
\end{abstract}

Keywords: Qualitative contours, descriptive data, Exploration method, geochemistry, (C-V) Fractal, Qaleh-Zari

\section{INTRODUCTION}

Mining activities especially copper mining in Iran are based on thousands of years ago. According to Khoei et al.[1] several copper ore bodies are recognized in Iran (more than 500 or so). Different zones of copper ore bodies are suggested by researchers. Bazin and Hubner [2] suggested five zones. Khoei et al.[1] suggested six copper ore bodies in Iran as illustrated in Figure 1.

Delineation of geochemical anomalies from background is one of the major targets in exploration geochemistry. In order to achieve this goal, different descriptive and quantitive methods have been employed [3]. All of these methods are quantitative including statistical procedures, Fractal/multi-fractal modeling, neural network methods and other common methods which are being used as well by the researchers and experts.

In this study, a new method named "qualitative contours" is introduced. This method is proposed and employed to recognize mineralization trends and deposits locations in the study area. Qualitative contours would be a pioneer for introduction and application of descriptive data in exploration activities generating valuable results with low costs. The simplicity in method application and result interpretation are the other features persuading experts to use this method. The application and results of this new method on Qaleh-Zari copper deposit are discussed in this paper. Fractal/multi-fractal modeling is used in this study in order to check and compare the results. Fractal modeling was firstly introduced by Mandelbort [4] and then developed by Cheng et al. [5] and Li et al. [6].

\section{GEOLOGY}

\subsection{Regional geology}

The geology of Iran is represented by an assembly of continental fragments initially rifted from Gondwana land. As the Paleotethys and Neotethys oceans developed and closed, the fragments subsequently amalgamated [7-12]. The geological studies and tectonic researches of Iran date back to more than five decades [13-25]. It can be claimed that Iran owns one of the most variable and complex conditions in the world from the view point of economic geology. Approximately most of the known metallic and nonmetallic mining resources observed in Iran are economic.

Urmieh-Dokhtar magmatic belt in Tertiary caused several ore deposits in Iran especially copper deposits such as Porphyry and Skarn deposits [27-37]. The other recognized copper deposit types in Iran are volcanic massive sulfide (VMS) and Hydrothermal vein type deposits. The Lut block and its contact with the other blocks around it could be mentioned as 


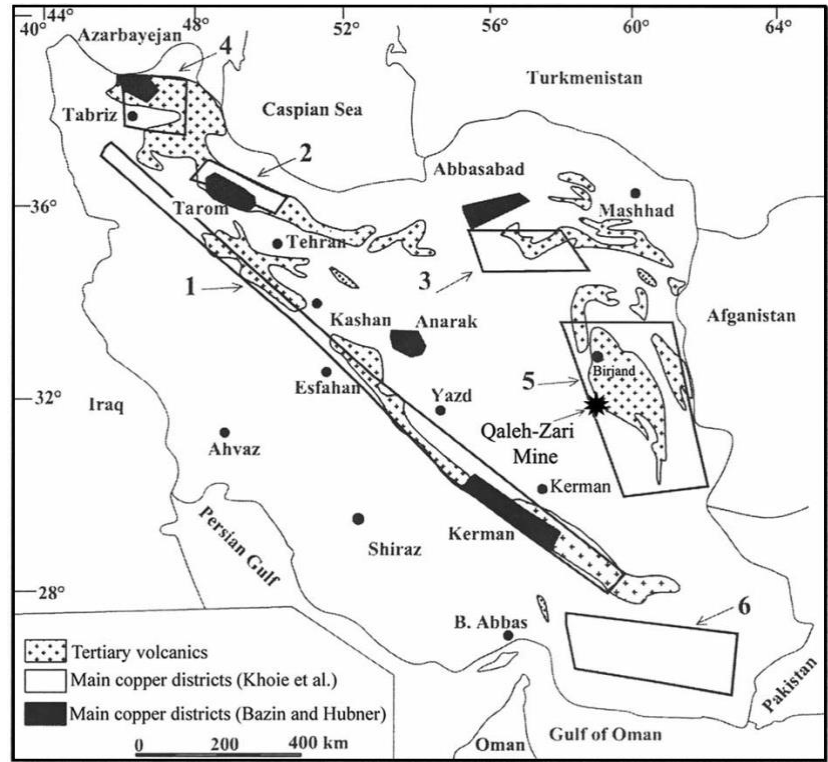

Fig. 1. The main zones of copper mineralization in Iran:

(1) Orumieh-Dokhtar Belt; (2) Western Alborz Zone;

(3) Kavir-Sabzevar Zone; (4) Sabalan; (5) Lut area; (6) Makran area [26]

one of the major locations for the VMS and hydrothermal vein type copper deposits. Figure 2 clearly demonstrates several Copper $(\mathrm{Cu})$ and LeadZinc ( $\mathrm{Pb}-\mathrm{Zn})$ mineralization localities in the Lut block.

\subsection{Qaleh-Zari copper deposit}

Qaleh-Zari copper deposit in the center of the Lut block is one of the most important copper deposits in Iran. Although the tonnage is low, the copper grade is high enough to assume Qaleh-Zari ore body as the noticeable one in Iran. This copper deposit is located $180 \mathrm{~km}$ southwest of Birjand city [26] as demonstrated in figure 1. Qaleh-Zari deposit, like most of the copper deposits in Iran, has been mined since more than 2000 years ago. Historic mining around the deposit is significant. It is worth mentioning that these historic mining activities were the most important exploration clues in the area. Qaleh-Zari is a $\mathrm{Fe}$-oxide $\mathrm{Cu}-\mathrm{Ag}$-Au vein type deposit [38].

Generally in hydrothermal vein type deposits structure of the area is the controller of hydrothermal fluids movement direction. The relationship between hydrothermal ore deposits and discontinuities in the crust (faults, fractures and lineaments) evokes that this deposit type is spatially consistent to regional structural features [40-63]. NW-SE and E-W trending could be considered for faults and fractures in this deposit, which also are the general structural trending in the whole area.

Qaleh-Zari copper deposit is located in the Lut block.

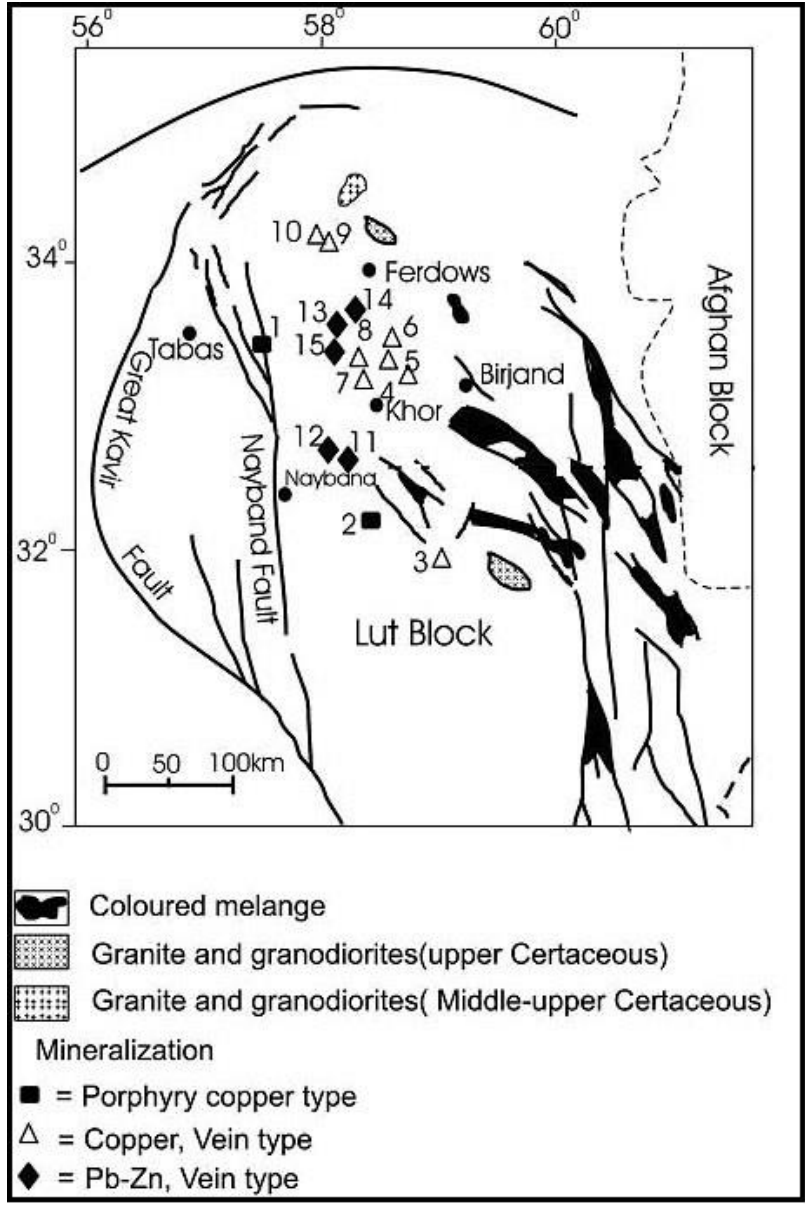

Fig. 2. Map of $\mathrm{Cu}, \mathrm{Pb}-\mathrm{Zn}$ mineralization localities in the Lut block. 1-Gazu, 2-Sorkh-Kuh, 3-Qaleh-Zari, 4Howze Dough, 5-Ghare Kaftar, 6-Shurk, 7-Shikasteh Sabz, 8- Mire Khash, 9-Madan-e-Rahi I, 10-Madan-eRahi II, 11- Sehchangi, 12-Howze Rasi, 13-Shurab, 14Gale Chah, and 15- Chah Nogre [39]

According to Daymehvar [64], the oldest formations are sedimentary rocks in the area. Paleogene volcanic rocks consist of high potassium calc-alkaline andesites (subduction zone shoshonites), andesitic basalts, dacites and rhyolites, andesitic and dacitic tuffs and pyroxenebearing andesites [65-67]. Basaltic rocks are the most abundant rock units in the area. Andesine and Andesitic basalt are the other major rock types observed in QalehZari area (Fig.3).

\subsection{MINERALIZATION}

A plutonic mass as the engine of a water circulation system has just created primary hydrothermal mineralization. Meteoric water plays an important role in enrichment and alteration processes in deposits associated with faults and fractures. Surface water flows can penetrate to deeper parts through the fractures. This process causes copper oxide minerals. The main copper mineral in Qaleh-Zari deposit is chalcopyrite. 
According to the deposit type, a variety of paragenesis minerals are expected and also observed. Beside

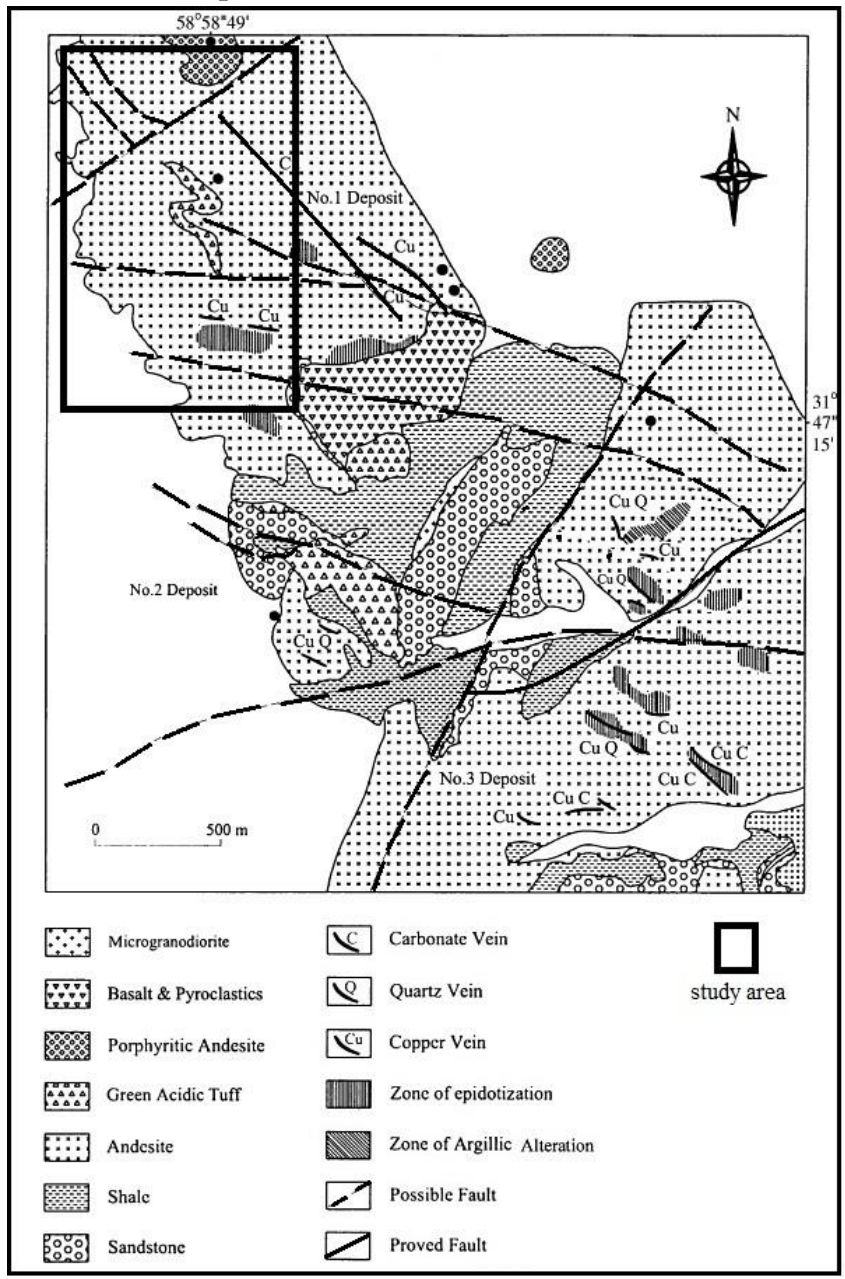

Fig.3 Geological Map of Qaleh-Zari Copper deposit (modified after Suzuki et al. [66] by Hassan-Nezhad and Moore [26])

chalcopyrite as the economic mineral, bornite, pyrite, hematite, galena, sphalerite, in sulfide supergene zone and malachite and aurite, in oxide supergene zone are the most common minerals in association with Quartz veins.

Four types of alterations are seen in Qaleh-Zari deposit. According to Hassan-Nezhad and Moore [26], these four alterations types are introduced as 1. sericitization; 2. argillization; 3. propylitization; and 4. Silicification.

\subsection{Structural geology}

In Qaleh-Zari deposit, mineralization is controlled by structural settings including faults and fractures with specific trending (NW-SE and $\mathrm{E}-\mathrm{W}$ trending). In hydrothermal deposits, structure of the deposit is very important to be studied since the mineralization is controled by the amount of fractures voulume which permits the hydrothermal fluid to pass through. The
Qaleh-Zari deposit is a fissure-filling polymetallic vein system formed by hydrothermal solutions circulating through fault planes and breccia zones [65], [67] and [68]. In this deposit, major and minor fractures within which copper mineralization has occured are created as the result of a Right-sided compressive shear deformation system with N135 general trending [69]. Faults and fractures can be grouped into the following orientations:

1. NW- SE, these right-lateral high angle faults (dipping about 868 ) host the main ore-bearing veins. Dilation in these faults sometimes reaches up to $70 \mathrm{~cm}$. 2. NE - SW, these barren fractures are younger than the other faults and fractures and show left-lateral movement. Locally, these fractures are seen to cut and displace ore-bearing veins, which occur along the oldest faults. 3. $\mathrm{N}-\mathrm{S}$, these fractures are the least common. Mineralization along these fractures is very poor and there is no evidence of mining along them. At the surface they are mostly mineralized by quartz and hematite. 4. $\mathrm{E}-\mathrm{W}$, faults from the point of view of mineralization are similar to Group 1 faults [26].

Based on the geological map (Fig.3) the study area includes NW-SE faults. It is noticeable that this trend for faults and fractures is controlling the mineralization in the area. Along the faults in the study area, copper mineralization is observed. These fractures are supposed as the most important structural features for mineralization in the study area. Thus sampling for the following method is mostly concentrated around these fractures.

\section{METHODOLOGY}

\subsection{Qualitative Contours method}

This method is devised and proposed by the authors of this paper for the first time. The primary targets of this new method are locating deposits and highlighting mineralization trends in study areas. The basis of this method is field observations. In other words, minerals, alterations and host rock observations are the input data which are recognized and recorded on the field. Exploration methods could be categorized in two major groups, quantitative and qualitative methods. Although many attempts have been taken to progress the first group, the second one has not been considered and improved as it should have been.

Generally field observations consists a bulk of geological datasets which could be categorized in several types such as structural features, mineralogy, surface and underground water conditions, chronology and etc. 
This method is supposed to delineate mineral deposits and mineralization trending in the area of study. Among the possible field observations mentioned above, mineralogy of the study area is the research subject of this method. Firstly before using this method, the area must be selected for a special element (target element). In the other words, the target element defined in primary exploration studies is what the researchers look for economical minerals of (oxide, sulfide and other forms). The other factor is paragenesis minerals. Paragenesis minerals for the target element (or mineral) are very important. Most of the time, paragenesis minerals are the best guidance leading to locate the specific mineralization or ore deposits. Alterations, as an important characteristic, play a critical role in exploration process. Most mineral deposit types and the all of hydrothermal deposits include alterations extended inside or around the deposit. The alterations and their specific minerals would be the third answer key for locating deposits. The last but not least is the host rock. The host/barren rocks, extending in the area and surrounding mineralization, are principle objects to be distinguished. The host rock types could be easily recognized in geological maps since the most extended and abundant rock types with obvious trending usually are the host rock of mineralization in the area.

These four factors (1- economic target minerals, 2paragenesis minerals, 3- alterations and 4- host rock) are the required field observations and the input data in Qualitative Contours method.

The data, as discussed above, is obtained from sampling on the field. Since there is no need to chemical analysis and the data is qualitative, just noting the observed minerals, alterations and host rock samples with the sampling location, is enough to create data set. It is recommended to observe at least 30 points in the area (thirty points are recomended as minimum number of samples needed to be considered as a statistical population as in classic statistics and also to make it possible to study the samples by classic statistics). The more samples the more accuracy in final results. There is no need to systematic sampling and also no force to scan and sample the whole area.

The next step is turning qualitative data into quantitative form. To achieve such goal, Table.1 is suggested. According to this table, the value for each sampling point could be defined. For illustration, the sampling point with economic target minerals is valued 4 scores and another sample point including any type of alterations in accordance to the target mineralization, is valued 2 scores. The same procedure for all the observation points is applied. Then these points and their values are plotted on a map based on the coordination of each sampling point. Thus the map includes some points (sampling points) with values 1, 2, 3 or 4 . By supposing these values as $Z$ value (Height) for each point, then it is possible to use these points to emerge a contour map (the first contour map). This contour map includes major contour lines (contour values 1, 2, 3 and 4).

Table1. Values for each type of observations (no dimension)

\begin{tabular}{|c|c|}
\hline Observation types & Value \\
\hline Host rock ( $1^{\text {st }}$ type $)$ & 1 \\
\hline $\begin{array}{c}\text { Alterations }\left(2^{\text {nd }} \text { type }\right) \\
\text { Paragenesis minerals ( }{ }^{\text {rd }} \\
\text { type })\end{array}$ & 2 \\
\hline $\begin{array}{c}\text { Economic target minerals } \\
\left(4^{\text {th }} \text { type }\right)\end{array}$ & 4 \\
\hline
\end{tabular}

Based on the samples, several poles or peak points may appear on this contour map. The poles or peak point's value is 4 . The poles are surrounded by other major contours. Each pole has an effective distance which separates it from other poles on the map. In this method enclosed area with contours 3 and 4 should be calculated. Then this calculated area is divided to the area of the whole region which is being studied. In the other words, the ratio of the enclosed area with contours 3 and 4 to the area of the whole study region should be calculated. This ratio value will be related to the poles of the map. This operation is critical because it creates dimensionless numbers and the dataset will be normalized to the total possible value (Total area) of the dataset. Then the value for each pole is a percent of the total area enclosed with contours 3 and 4 around the pole. In the next step, the value of each pole (the ratio value) will be related to the poles. A new contour map (Mineralization trend map) could be created for these poles based on their values. The mineralization's trending will be obviously recognizable in this map which could be demonstrated as arrows drawn from the center of areas enclosed with low contour values to the center of areas enclosed with high contour values.

The other noticeable feature of the first contour map is modeling the rock types of the whole area. There is no need to clarify that there are infinite numbers between two single numbers. Thus between 1, 2, 3 and 4 (the 
observation type values) there are several definable numbers. As an example it is possible to define 2.5 between 2 and 3 then the contour value of 2.5 (between the two major contours 2 and 3) suggests mineralogy phase between alterations and paragenesis minerals. This is extendable to other minor contours determined by any interval number for the contour map.

These are not the only performances of these contours. The other beneficial one is using the map to estimate erosion levels in the area. Erosion levels are important factors for deposit position evaluation. The contours exactly suggest what should exist on the field then if there would be any differences with the contour map suggestions and field observations, erosion levels must be determined. In the other words, the differences mean that the expected mineralogy/lithology type has been eroded or burred previously. This method in this feature is highly more effective than a lithological map. Although in order to create a lithological map the whole areas and the whole rock unites and outcrops must be considered, there is no need to sampling the whole area for creating a qualitative contour map suggested by this study.

The contours (in the first contour map) created in this way evoke that the points are fractally distributed. To prove this claim, concentration-area (C-A) Fractal modeling has been applied for the areas enclosed by the qualitative contours. Since both methods are envolved with contours and surfacial study, fractal modeling is used. Concentration-area (C-A) Fractal modeling is introduced and expressed by Cheng et al. (1994) as: A (p) denotes the area with concentration values greater than the contour value $\mathrm{p}$. This implies that $\mathrm{A}(\mathrm{p})$ is a decreasing function of $\mathrm{p}$. If $\mathrm{v}$ represents the threshold, the following empirical model generally provides a good fit to the data for different elements in the study area:

$$
A(p \leq v) \propto p^{-\alpha_{1}} \quad A(p>v) \propto p^{-\omega_{2}}
$$

Where $\propto$ denotes proportionality.

\subsection{Concentration-Volume (C-V) Fractal modeling}

Concentration-volume (C-V) fractal modeling is similar to concentration-area $(\mathrm{C}-\mathrm{A})$ fractal modeling with the difference that instead of enclosed area, the volume is employed so the final result is expected to be a $3 \mathrm{D}$ anomaly model. This method is expressed as the following statements:

$\mathrm{V}(\rho \leq \mathrm{V}) \propto \rho^{-\mathrm{a} 1} ; \mathrm{V}(\rho \geq \mathrm{V}) \propto \rho^{-\mathrm{a} 2}$ where $V(\rho \leq v)$ and $V(\rho \geq v)$ represent the two volumes with concentration values less than or equal to and greater than or equal to the contour value $\rho$; $v$ represents the threshold value of a geological zone (or volume); and a1 and a 2 are the characteristic exponents. The break points in Log-Log plot in this method could be assumed as threshold values for geochemical populations. Based on the break points, background and anomaly are distinguished.

\section{DISCUSSION}

\subsection{Qualitative contours method application}

In this research, the new introduced method (Qualitative Contours method) is applied on Qaleh-Zari area (including Qaleh-Zari deposit) and the results are discussed. As mentioned before, Qualitative Contours method is kind of empirical procedures meaning that field observation (mineralogical/lithological features) are the input data.

In Qaleh-Zari area, the prospecting element or the target element is Copper. In the other words, locating copper mineralization is the goal of the study in this area and this research. To achieve this goal, the authors represent and suggest the new method Qualitative Contours. To begin with, 80 surface samples are collected from an area of about $46 \mathrm{~km}^{2}$ north of Qaleh-Zari deposit. Mineralogical/lithological observations and location coordinates for each sample are recorded. According to the basis of Qualitative Contours method, the samples are categorized in four types. Some of the samples containing copper minerals (malachite, azurite, copprite) are grouped as the $4^{\text {th }}$ type. Other samples in which paragenesis minerals for copper mineralization (magnetite, specularite, pyrite and gallena) are found are the $3^{\text {rd }}$ type. As the same procedure, samples with any type of alterations (propylitic, silicic, argillic and potassic) excluding copper minerals or copper paragenesis minerals are the $2^{\text {nd }}$ group and host/barren rock samples form the $1^{\text {st }}$ type. The samples credited based on table 1 are plotted according to their coordinates and then the contour map is created in Surfer.11 software (Fig.4).

At the first look, each contour line recommends an equal feature for the points on it like any other contour map. This qualitative contour map suggests constant mineralogy/lithology for each contour line. In order to control the accuracy of the map, authors followed all major contours on the field according to the map (Fig.4). The result was extremely correlated to what the map was predicting. The qualitative contours not only do define different mineralogy/lithology types in the 
area but also demonstrates geological features especially faults and fractures along the contours lines. Since this method is based on mineralogy and minerals are usually deposited along the fractures and faults,

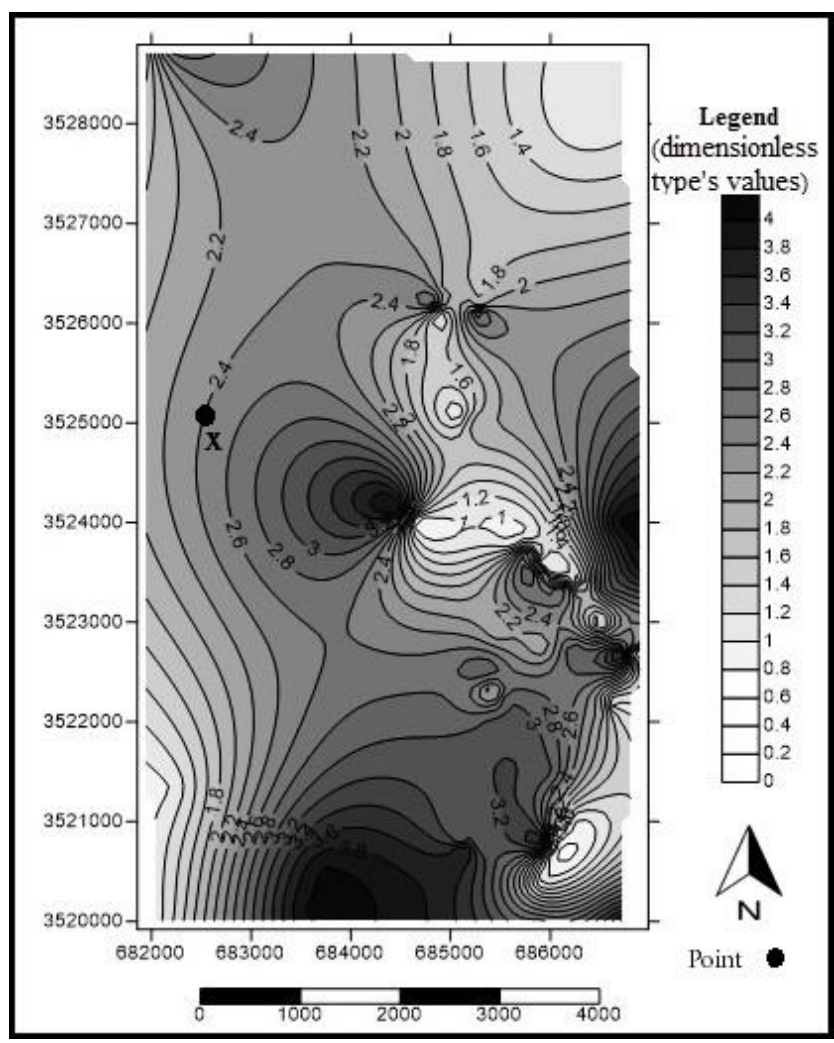

Figure 4. Contour map based on Qualitative contours method, $\mathrm{X}$ is an accuracy check point observed after runing the method.

when minerals observation locations are taken into account, the faults and fractures will be automatically mapped in mineralization maps along the mineralization trends and in addition, based on field observations in the area, the faults and fractures where oriented along the contours in figure4. Figures $5 \mathrm{a}$ and $5 \mathrm{~b}$ show areas delineated by qualitative contours method as $4^{\text {th }}$ and $1^{\text {st }}$ types respectively.

As illustrated in figure 5a, copper-included quartz veins could be obviously distinguished on the surface. This vein is exactly located as contour value 4 in the qualitative contours map. Figure 5b shows basaltic host rocks in the area and it worth mentioning that their contour value on the qualitative contours map is 1 which proves the accuracy of the map.

The other aspect to point out is erosion level. Based on the qualitative contours map, erosion levels and conditions could be relatively determined. According to the qualitative contours map (Fig.4), in the point X, the contour value is 2.4 but instead of semi altered basalt (equivalent to contour 2.4 in the area), sediment in water stream is observed. This stream has created a valley between two hills that the qualitative contours map shows a constant value (similar mineralogy/lithology) for both hills. It means that previously there was the same mineralogy/lithology, as the two hills, in the point $\mathrm{X}$ before the stream activity

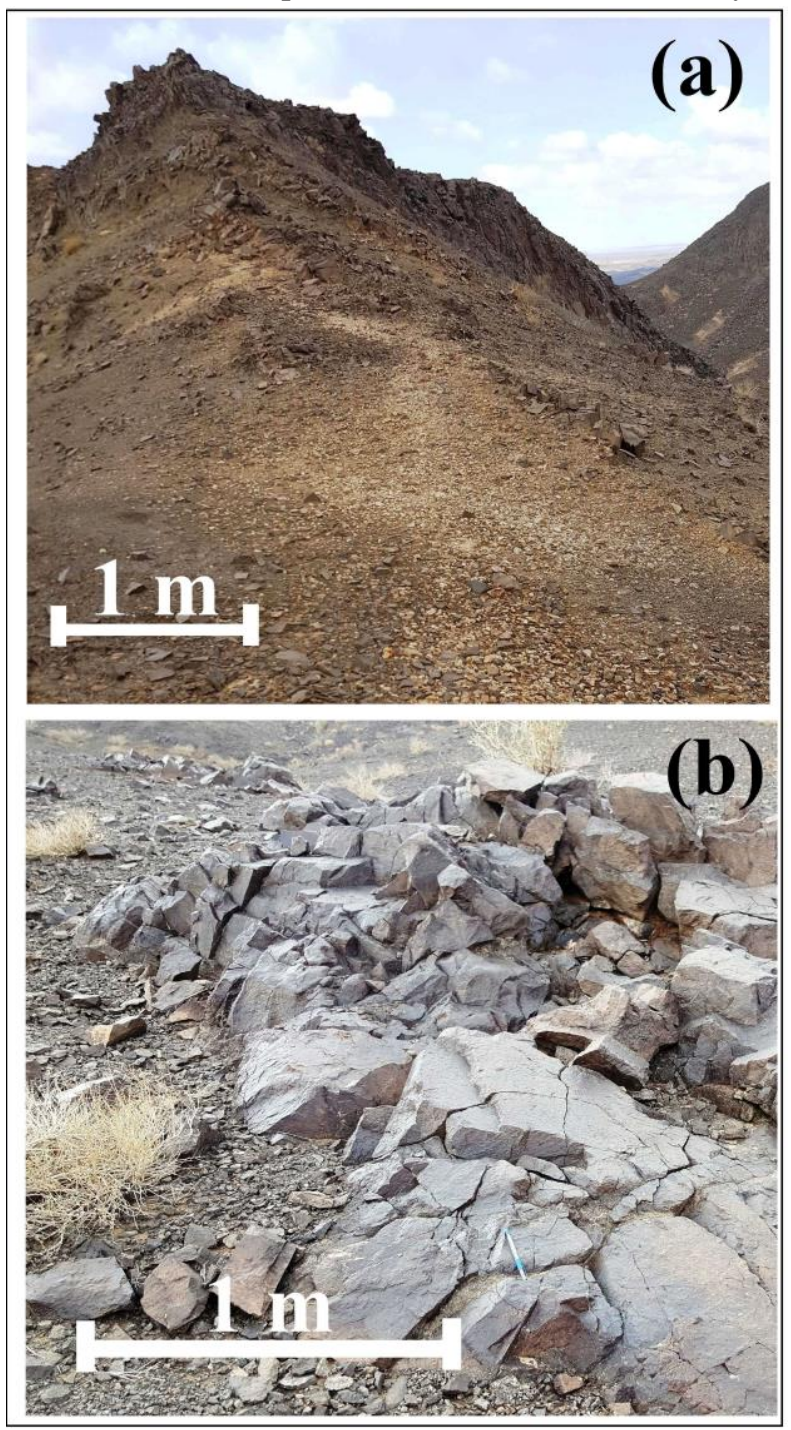

Figure 5. Field observations based on qualitative contours map. a) silicified veins including malachite, b) host rock outcrops

causing erosion in this point. This story is extensible to parts of the area with differences in qualitative contours value and field observations.

As another approach to this method, enclosed area by contour lines is the subject. In this method type 3 and type 4 (based on table 1) are claimed as anomalous segments of the dataset. The definition of anomaly in this case is the mineralization occurrence. In the other words, it is expected that this method demonstrates and highlights mineralized areas. One of the most frequently used methods to delineate anomalies related to enclosed areas by contour lines is Concentration-Area (C-A) 
Fractal modeling. This method is applied to the areas enclosed by qualitative contours. The Log-Log plot (Log (value)-Log (area)) (Fig.6) shows a major breakpoint in 0.48 which is equal to 3.019 if antilog function be applied. It means points with values greater than 3.019 are the anomalous samples so based on table $1,1^{\text {st }}$ and $2^{\text {nd }}$ types are background and $3^{\text {rd }}$ and $4^{\text {th }}$ types are anomalous data. Thus this method is highly correlated to the well-known Concentration-Area (C-A) Fractal modeling since both methods are suggesting the same anomaly threshold.

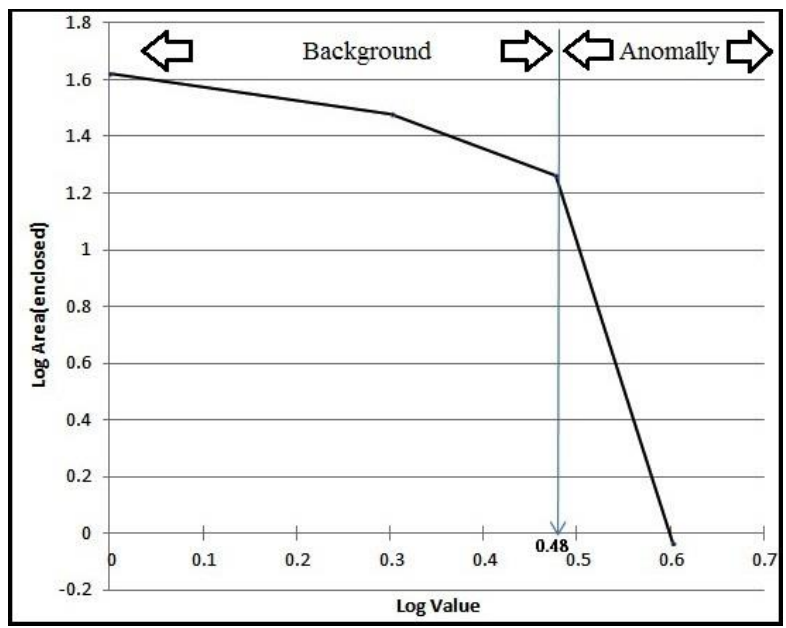

Figure 6. Log (value)-Log (area) plot based on (C-A) Fractal modeling

In addition, Mineralization trend map creation is possible by the use of qualitative contours map. As described in methodology section, enclosed area for contours 3 and 4 in the map (Fig.4) is calculated for each pole and is divided to the area of the whole study region. The result is a dimensionless value related to each pole. Then the contour map (Fig.7) is created in Surfer.11 software. This contour map is the Mineralization trend map. This map shows mineralization trend in the area increasing from north to south since the ratio percentage (enclosed area of contours 3 and 4 to the area of the whole region) increases.

This mineralization trend map suggests a mineralization gradient in the area. Based on the map, Southern parts are more potential for copper mineralization. It worth mentioning that Qaleh-Zari copper deposit is exactly located in southern regions out of the map. As a result, mineralization trend according to the Qualitative Contours method is just directing to the most mineralized area which would be very useful in the primary exploration steps.

\subsection{Anomaly accuracy check}

In this study, Qaleh-Zari area is investigated. The Qualitative Contours method is used and applied to an area located north of the deposit to see whether this method is capable to recognize the deposit. Since the method successfully worked, Qaleh-Zari deposit is the

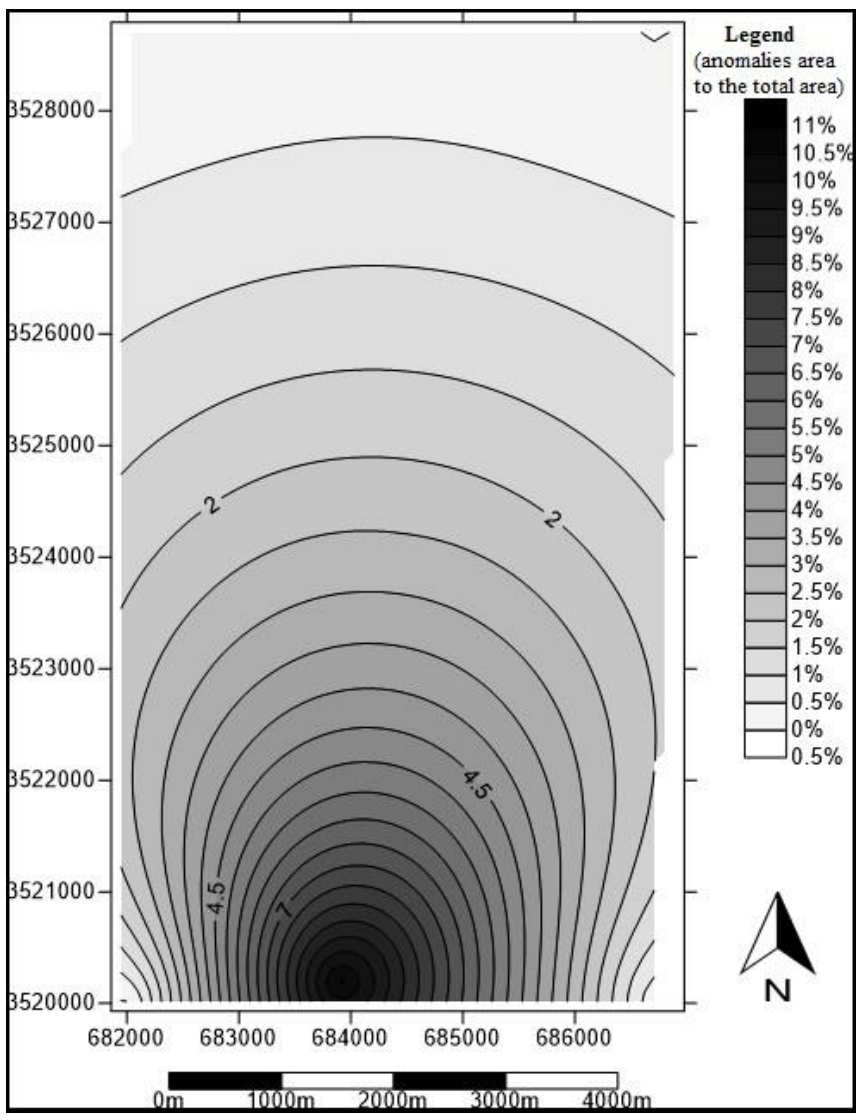

Figure 7. Mineralization trend map based on the Qualitative Contours Method.

next case study to prove the accuracy of geochemical copper anomalies suggested by the Qualitative Contours method in southern parts of the mineralization trend map (Fig.7) which is well-known Qaleh-Zari deposit. To determine copper geochemical anomaly in QalehZari copper deposit, 20 boreholes are drilled. The boreholes are drilled to simulate the condition that Qaleh-Zari deposit was not known for the researchers. This will control the results numerically. The cores obtained from the boreholes are used for sampling. In this case, 140 samples are derived from these boreholes and analyzed by ICP-MS (Inductively coupled plasmamass spectrometry). The analysis result for copper is shown in table 2. To avoid large data table, only average copper content for each borehole is displayed in table 2 . 
Table 2. Boreholes average $\mathrm{Cu}$ content

\begin{tabular}{|c|c|}
\hline $\begin{array}{c}\text { Borehole } \\
\text { number }\end{array}$ & $\begin{array}{c}\text { Average Cu } \\
(\mathrm{ppm})\end{array}$ \\
\hline 1 & $5-18$ \\
\hline 2 & $10-100$ \\
\hline 3 & $60-8100$ \\
\hline 4 & $1400-49500$ \\
\hline 5 & $20-400$ \\
\hline 6 & $40-5100$ \\
\hline 7 & $35-70$ \\
\hline 8 & $30-60$ \\
\hline 9 & $50-1000$ \\
\hline 10 & $2600-11000$ \\
\hline 11 & $30-89400$ \\
\hline 12 & $200-16900$ \\
\hline 13 & $30-90$ \\
\hline 14 & $40-12600$ \\
\hline 15 & $30-45$ \\
\hline 16 & $100-8300$ \\
\hline 17 & $22-3900$ \\
\hline 19 & $70-11000$ \\
\hline & 1190 \\
\hline 10 & \\
\hline $13-17500$ \\
\hline 13
\end{tabular}

Concentration-Volume (C-V) Fractal modeling is employed to define geochemical populations for the analysis results. To apply this Fractal method, volume per each grade is required. Thus the 3Dimentional model should be created. This model is created in Rockworks.14 software by Inverse Distance Weighting algorithm with cell size of 20 meters and then the volume per each grade is calculated. The Log-Log plot (Log (grade)-Log (volume)) (Fig.8) shows different geochemical populations in Qaleh-Zari copper deposit.
Based on the Concentration-Volume (C-V) Fractal modeling, anomaly threshold for copper samples is $1995 \mathrm{ppm}$. This grade is applied to the 3Dimentional model of the deposit to create anomaly model (Fig.9).

According to the anomaly model, the economic copper deposit with threshold of 1995ppm is delineated and proved. Thus the Qualitative Contours method also is successful in locating mineral deposits as applied for Qaleh-Zari Copper deposit.

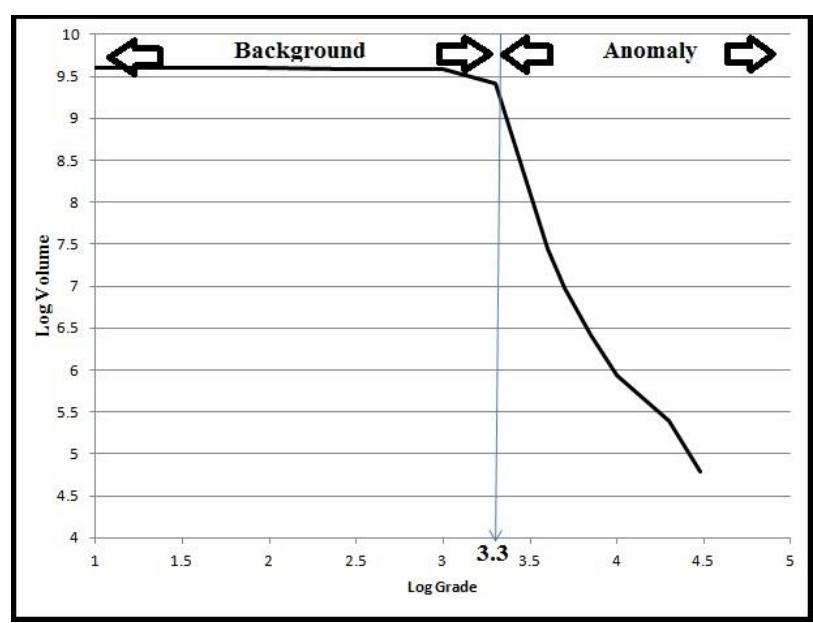

Figure 8. Log (grade)-Log (volume) plot based on (CV) Fractal modeling.

\section{CONCLUSION}

Among different exploration methods, there are few procedures paying attention to qualitative data. Qualitative data arrangement is so much more cost and time effective than the so called quantitative datasets.

Quantitative datasets include systematic sampling, expensive chemical analysis and complex data processing. The Qualitative Contours method introduced by this research opens the way forward to use qualitative and descriptive data. The data are based on field observations and there is no need to chemical analysis. This effective method is highly recommended in primary exploration steps and in projects with financial limitations. As discussed, this method is capable to delineate mineralization trends in a prospecting area which causes to locate mineral deposits. 


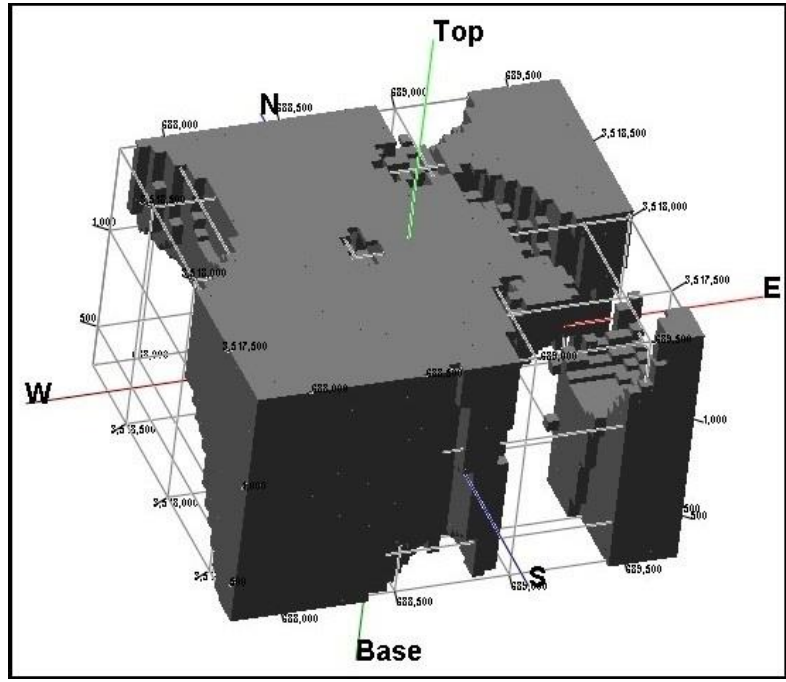

Figure 9. The 3Dimentional anomaly model of QalehZari deposit based on (C-V) Fractal modeling

The other important feature is the lithology modeling which the Qualitative Contours map suggests. According to the map, contours are defined as a type of mineralogy or lithology meaning that the type is constant on each single contour. This could be helpful and replaced to lithological map in a prospecting area since the contours are highly correlated to the geological field observations. Based on this fact, eroded unites in the area are easily recognized by the comparison between the qualitative contour map and the field observations. This method also is in high correlation to quantitative methods especially Fractal modeling. The anomalies based on both methods overlap each other that will encourage other researchers to use this new method for exploration purposes.

\section{REFERENCES}

[1] Khoei, N., Ghorbani, M., Taj-Baksh, P., 1999. Copper Deposits in Iran. GSI, Tarhe-Ketab (421 pp., (in Persian)).

[2] Bazin, D., Hubner, H., 1969. Copper deposits in Iran. Geological Survey of Iran, Internal Report No. 13, p. 195 (in English)

[3] Agharezaei, M. and Hezarkhani, A. (2016) Delineation of Geochemical Anomalies Based on $\mathrm{Cu}$ by the Boxplot as an Exploratory Data Analysis (EDA) Method and ConcentrationVolume (C-V) Fractal Modeling in Mesgaran Mining Area, Eastern Iran. Open Journal of Geology, 6, 1269-1278.

[4] Mandelbort, B.B. (1982) The Fractal Geometry of Nature. Freeman, San Francisco, 460 p.

[5] Cheng, Q., Agterberg, F.P. and Ballantyne, S.B. (1994) The Separation of Geochemical Anomalies from Background by Fractal Methods. Journal of Geochemical Exploration, 51, 109-130. http://dx.doi.org/10.1016/0375-6742(94)90013-2

[6] Li, C., Ma, T. and Shi, J. (2003) Application of a Fractalmethod Relating Concentrations and Distances for Separation of Geochemical Anomalies from Background. Journal of Geochemical Exploration, 77, 167-175. http://dx.doi.org/10.1016/S0375-6742(02)00276-5

[7[ Alavi, M., 1996. Tectonostratigraphic synthesis and structural style of the Alborz Mountains system in northern Iran. J. Geodyn. 11, 1-33.

[8] Berberian, M., King, G.C.P., 1981. Towards a paleogeography and tectonic evolution of Iran. Can. J. Earth Sci. 18 (2), 210-265.

[9] Meshkani, A., Mehrabi, B,. Yaghubpur, A., Sadeghi, M., 2013. 'Recognition of the regional lineaments of Iran: Using geospatial data and their implications for exploration of metallic ore deposits', Ore Geology Reviews, 55(0169-1368), pp. 48-63.

[10] Sengör, A.M.C., 1987. Tectonics of the Tethysides: orogenic collage development in a collisional setting. Annu. Rev. Earth Planet. Sci. 15, 213-244.

[11] Stocklin, J., 1968. Structural history and tectonics of Iran: a review. Am. Assoc. Petrol. Geol. Bull. 52, 1229-1258.

[12] Stocklin, J., 1977. Structural correlation of the Alpine ranges between Iran and central Asia. J. Geol. Soc. Fr. Mem. H. Ser. 8, 333353.

[13] Stocklin, J., 1974. A-Northern Iran: Alborz mountains. Mesozoic - Cenozoic orogenic Belt, data for orogenic studies (Ed.), The TRANSMED Atlas: The Mediterranean Region from Crust to Mantle. Springer, New York, pp. 53-80. In: Spenncer, A.M. (Ed.), Geol. Soc., London, Sp. Pub4. Scottish Academic Press, pp. 213-234.

[14] Sengör, A.M.C., 1984. The Cimmeride orogenic system and the tectonics of Eurasia. Geol. Soc. Am. Spec. Pap. 195, $1-82$

[15] Sengör, A.M.C., Altiner, D., Cin, A., Ustaomer, T., Hsu, K.J., 1988. Origin and assembly of the Tethyside orogenic collage at the expense of Gondwanaland. In: Audley- Charles, M.G., Hallaml, A. (Eds.), Gondwana and Tethys. Geol. Soc. Lond. Spec. Publ. 37, pp. 81-119.

[16] Davouzadeh, M., Schmidt, K., 1984. A review of the Mesozoic paleogeography and paleotectonic evolution of Iran. N. Jahrb. Geol. Palaontol. Abh. 68, 182-207.

[17] Kazmin, V.G., 1991. Collision and rifting in the Tethys Ocean: geodynamic implications. Tectonophysics 196, 371384. 
[18] Boulin, J., 1991. Structures in Southwest Asia and evolution of the eastern Tethys. Tectonophysics 196, 211268.

[19] Alavi, M., 1994. Tectonic of the Zagros orogenic belt of Iran: new data and interpretations. Tectonophysics 229, 211239.

[20] Ramezani, J., Tucker, R.D., 2003. The Saghand region, central Iran: $\mathrm{U}-\mathrm{Pb}$ geochronology, petrogenesis and implications for Gondwana tectonics. Am. J. Sci. 303, 622665.

[21] Stampfli, G.M., Borel, G.D., 2004. The TRANSMED transects inspace and time: constraints on the paleotectonic evolution of the Mediterranean domain. In: Cavazza, W., et al.

[22] Bagheri, S., Stampfli, G.M., 2008. A new litho-structural subdivision for the Palaeotethys terranes in central Iran (Anarak, Jandaq and Posht-e-Badamareas) and its geodynamic implications.

[23] Hassanzadeh, J., Stockli, D.F., Horton, B.K., Axen, G.J., Stockli, L.D., Grove, M., Schmitt, A.K., Walker, J.D., 2008. $\mathrm{U}-\mathrm{Pb}$ zircon geochronology of late Neoproterozoic-Early Cambrian granitoids in Iran: implications for paleogeography, magmatism, and exhumation history of Iranian basement. Tectonophysics 451, 71-96.

[24] Omrani, J., Agard, P., Whitechurch, H., Benoit, M., Prouteau, G., Jolivet, L., 2008. Arcmagmatism and subduction history beneath the Zagros Mountains, Iran: a new report of adakites and geodynamic consequences. Lithos 106, 380-398.

[25] Agard, P., Yamato, P., Jolivet, L., Burov, E., 2009. Exhumation of oceanic blueschists and eclogites in subduction zones: timing and mechanisms. Earth Sci. Rev. 92, $53-79$.

[26] Hassan-Nezhad, Ali A. and Farid Moore., 2005. "A Stable Isotope And Fluid Inclusion Study Of The QalehZaricu-Au-Ag Deposit, Khorasan Province, Iran". Journal of Asian Earth Sciences 27.6: 805-818.

[27] Forster, H., 1978. Mesozoic-Cenozoic metallogenesis in Iran. J. Geol. Soc. Lond. 35, 443-455.

[28] Hezarkhani, A., 2007. Geochemistry of the Enjerd skarn and its association with copper mineralization, northwestern Iran. Int. Geol. Rev. 48, 892-909.

[29] Hezarkhani, A., 2008. A fluid inclusion investigation hydrothermal evolution of the Miduk porphyry copper system, Kerman, Iran. Int. Geol. Rev. 50, 665-684.

[30] Karimzadeh Somarin, A., Moayyed, M., 2002. Graniteand gabbrodioriteassociated skarn deposits of NW Iran. Ore Geol. Rev. 20, 127-138.
[31] Mollai, H., Sharma, R., Pe-Piper, G., 2009. Copper mineralization around the Ahar batholith, north of Ahar (NW Iran): evidence for fluid evolution and the origin of the skarn ore deposit. Ore Geol. Rev. 35, 401-414.

[32] Shafiei, B., Haschke, M., Shahabpour, J., 2009. Recycling of orogenic arc crust triggers porphyry $\mathrm{Cu}$ mineralization in Kerman Cenozoic arc rocks, southeastern Iran. Miner. Deposita 44, 265-283.

[33] Shafiei, B., 2010. Lead isotope signatures of the igneous rocks and porphyry copper deposits from the Kerman Cenozoic magmatic arc (SE Iran), and their magmaticmetallogenetic implications. Ore Geol. Rev. 38, 27-36.

[34] Shahabpour, J., 1982. Aspects of alteration and mineralization at the Sar Cheshmeh copper-molybdenum deposit, Kerman, Iran. (Unpublished $\mathrm{PhD}$ thesis) Leeds University, Leeds, U.K.(342 pp.).

[35] Waterman, G.C., Hamilton, R.L., 1975. The Sar Cheshmeh porphyry copper deposit. Econ. Geol. 70, 568-576.

[36] Zarasvandi, A., Liaghat, S., Zentilli, M., 2005. Porphyry copper deposits of the Urumieh- Dokhtar magmatic arc, Iran. In: Porter, T.M. (Ed.), Super Porphyry Copper \& Gold Deposits, A Global Perspective. PGC Publishing, Adelide (13 pp.).

[37] Zarasvandi, A., Liaghat, S., Zentilli, M., 2007. Geology of the Darreh-Zerreshk and Ali- Abad porphyry copper deposits, Central Iran. Int. Geol. Rev. 47, 620-646.

[38] Karimpour, M.A., Khin Zaw, D.L. Huston., 2005. 'S-C-O Isotopes, Fluid Inclusion Microthermometry, and the Genesis of Ore Bearing Fluids at Qaleh-Zari Fe-Oxide $\mathrm{Cu}-\mathrm{Au}-\mathrm{Ag}$ Mine, Iran', Journal of Sciences, Islamic Republic of Iran, 16(2)(1016-1104), pp. 153-168 (2005).

[39] Tarkian M., Lotfi M., and Baumann A. Magmatic copper and Lead Zinc ore deposits in the Central Lut, Eastern Iran. $N$. Jb. Geol. Palaont. Abh., 168(2/3): 497-523 (1984).

[40] Bierlein, F.P., Murphy, F.C., Weinberg, R.F., Lees, T., 2006. Distribution of orogenic gold deposits in relation to fault zones and gravity gradients: targeting tools applied to the Eastern Goldfields, Yilgarn Craton, Western Australia. Miner. Deposita 41, 107-126.

[41] Grauch, V.J.S., Rodriguez, B.D., Bankley, V., 2003. Evidence for a Battle Mountain-Eureka crustal fault zone, north-central Nevada, and its relation to NeoproterozoicEarly Paleozoic continental breakup. J. Geophys. Res. 108 (B3), 2140. 
[42] Groves, D.I., Vielreicher, R.M., Goldfarb, R.J., Condie, K.C., 2005. Controls on the heterogeneous distribution of mineral deposits through time. In: McDonald, I., Noyce, A.J., Butler, I.B., Herrington, R.J., Polya, D.A. (Eds.), Mineral Deposits and Earth Evolution: Geological Society, London, Special Publications, 248, pp. 71-101.

[43] Groves, D.I., Bierlein, F.P., 2007. Geodynamic settings of mineral deposit systems. J. Geol. Soc. 164, 19-30.

[44] Haynes, D.W., 2002. Giant iron oxide-copper-gold deposits: are they in distinctive geological settings? In: Cooke, D.R., Pongratz, J. (Eds.), Giant Ore Deposits: Characteristics, Genesis and Exploration. : CODES, Special Publication, 4. Hobart, Tasmania, pp.

57-77.

[45] Kerrich, R., Goldfarb, R.J., Richards, J., 2005. Metallogenic provinces in an evolving geodynamic framework. Economic Geology 100th Anniversary. 10971136.

[46] Sillitoe, R.H., 1972. Relation of metal provinces in western America to subduction of oceanic lithosphere. Bull. Geol. Soc. Am. 83, 813-818.

[47] Sillitoe, R.H., 2000. Gold-rich porphyry deposits: descriptive and genetic models and their role in exploration and discovery. Rev. Econ. Geol. 13, 315-345.

[48] Billingsley, P., Locke, A., 1941. Structure of ore districts in the continental framework. Am. Inst. Min. Metall. Eng. Trans. 144, 964.

[49] Kutina, J., 1969. Hydrothermal ore deposits in the western United States: a new concept of structural control of distribution. Science 165, 1113-1119.

[50] Kutina, J., 1971. The Hudson Bay Paleolineament and anomalous concentration of metals along it. Econ. Geol. 66, 314-325.

[51] Kutina, J., Fabbri, G., 1972. Relationship of structural lineaments and mineral occurrences in Abitibi area of the Canadian Shield. Geol. Surv. Can. Pap. 71-9, 36.

[52] Kutina, J., 1974a. Structural control of volcanic ore deposits in the context of global tectonics. Bull. Volcanol. 38, 1038-1069.

[53] Kutina, J., 1974b. Relationship between the distribution of big endogenic ore deposits and the basement fracture pattern. Examples from four continents. Proceedings of the First International Conference on the New Basement Tectonics: Utah Geol. Assoc. Publ., vol. 5, pp. 565-593.
[54] Kutina, J., 1975. Tectonic development and metallogeny of Madagascar with reference to the fracture pattern of the Indian Ocean. Bull. Geol. Soc. Am. 86, 582-592.

[55] Kutina, J., 1980. Regularities in the distribution of ore deposits along the Mendocino latitude Western United States. Global Tecton. Metallog. 1, 134-193.

[56] Kutina, J., 1983a. Global tectonics andmetallogeny; deep roots of some ore-concentrating fracture zones. A possible relation to small-scale convective cells at the base of lithosphere. Adv. Space Res. 3, 201-214.

[57] Kutina, J., 1983b. Similarities in the deep-seated controls of mineralization between the United States and China. Global Tecton. Metallog. 2, 111-142.

[58] Kutina, J., 1986. The role of basement tectonics in the distribution of some major ore deposits of Mesozoic and Cenozoic ages. In: Jiqing, Huang (Ed.), Proceedings of the Symposium on Mesozoic and Cenozoic Geology in Connection of the 60th Anniversary of the Geological Society of China.

[59] Kutina, J., 1988. Criteria indicating a block structure of the upper mantle and its role in metallogeny. Proceedings of the Seventh Quadrennial IAGOD Symposium, pp. 111-120.

[60] Favorskaya, M.A., Vinogradov, N.V., 1991. Geological evolution of ore-concentrating lineaments. Global Tecton. Metallog. 1 (1-2), 75-84.

[61] Richards, J.P., 2000. Lineaments revisited. Soc. Econ. Geol. Newsl. 42 (1), 14-20.

[62] Chernicoff, C.J., Richards, J.P., Zappettini, E.O., 2002. Crustal lineament control on magmatism and mineralization in northwestern Argentina: geological, geophysical, and remote sensing evidence. Ore Geol. Rev. 21, 127-155.

[63] Sillitoe, R.H., 2010. Porphyry copper systems. Econ. Geol. 105, 3-41.

[64] Daymehvar, M., 1996. Study of geology, mineralogy, geochemistry and genesis of Qaleh-Zari copper deposit. Unpublished MSc Thesis. Teacher Training University, p. 133 (in Farsi).

[65] Sadaghyani-Avval, F., 1976. Etude géologique de la re'gion de la mine de Khal- Eh-Zari (Iran) mineralisation et inclusions fluids. Unpublished $\mathrm{PhD}$ Thesis, Universite' de Nancy, Nancy, p. 165.

[66] Suzuki, Y., Ogawa, K., Akiyama, N., 1976. Copper ores from the Qaleh-Zari Mine, Iran. Mining Geology 385, 26391.

[67] Moore, F., Hassan-Nezhad, A.A., 1994. Fluid inclusion study of mineralization at the Qaleh-Zari Mine, South 
International Journal of Science and Engineering Applications

Volume 7-Issue 02, 08-19, 2018, ISSN:-2319-7560

Khorasan, Iran. Iranian Journal of Science and Technology 18, 213-223.

[68] Karimpour, M.H., Zaw, K., 2000. Geothermometry and physicochemical condition of Qaleh-Zari $\mathrm{Cu}-\mathrm{Au}$ ore bearing solution based on chlorite composition and fluid inclusion study. Iranian Journal of Crystallography and Mineralogy 8, 3-22 (in Farsi with English abstract).
[69] Khatib, M, M,. 1999. The relationship between shear deformation and mineral veins in Qaleh-Zari. In the congerence of recognition of mining potentials in eastern Iran, Birjand. 